khả năng gây bệnh nếu cá thể phòng vệ và đối phó kém. Tuy nhiên, thành phần gây bểnh của sang chấn tâm lý là ý nghĩa thông tin chứ không chỉ là cường độ của sang chấn và ý nghĩa thông tin đóng vai trò quan trọng hơn.

\section{KẾT LUẬN}

Bệnh nhân rối loạn loạn thần cấp và nhất thời có tỷ lệ cao có sang chấn tâm lý

Phần lớn sang chấn tâm lý là khó khăn về kinh tế và xuất hiện trên 2 tuần trước khi bị bệnh, có cường độ, ý nghĩa ở mức vừa phải.

\section{TÀI LIẸU THAM KHẢO}

1. Trần Hữu Bình (2001). Rối loạn loạn thần cấp và nhất thời. Bênh học tâm thần. Bộ mồn tâm thần Đai học Y Hà Nội, 38-43.

2. Tổ chức y tế thế giới (WHO) (1992), Rối loạn loạn thần cấp và nhất thời, Phân loại cảc rối loạn tâm thần và hành vi ICD-10, World Health Organization, Geneva, 91-94.

3. Rusaka M. and Rancāns E. (2014). A prospective follow-up study of first-episode acute transient psychotic disorder in Latvia. Ann Gen Psychiatry, 13(1), 4.

4. Vương Đình Thuỷ (2018), Nghiên cứu đặc điểm lâm sàng và một số yếu tố liên quan đến rối loạn loạn thần cấp và nhất thời, luận văn cao học, Trường đại học Y Hà Nội, Hà Nội., .

5. Castagnini A.C., Munk-Jørgensen $P_{.}$, and Bertelsen A. (2016). Short-term course and outcome of acute and transient psychotic disorders: Differences from other types of psychosis with acute onset. Int J Soc Psychiatry, 62(1), 51-56.

6. Marija R. (2015), Acute and Transient Psychotic Disorder (ATPD) Dynamic Development and Particularities in Diagnostics and Treatment in Latvia. Summary of the Doctoral Thesis, Dr. med., Rīga Stradinš University.

\title{
ĐĂC ĐIỂM LÂM SÀNG, CÂ̂N LÂM SÀNG BỆNH NHÂN UNG THƯ PHỔI KHÔNG TẾ BÀO NHỎ DI CĂN NÃO CÓ ĐộT BIẾN EGFR TẠI BỆNH VIỆN BẠCH MAI
}

\section{TÓM TẮT}

Mục tiêu: Mô tả đặc điểm bệnh nhân ung thư phổi không tế bào nhỏ di căn não có đột biến EGFR tại Bệnh viện Bạch Mai. Đối tượng và phương pháp nghiên cứu: Nghiên cứu hồi cứu, mô tả, cắt ngang trên 53 bệnh nhân được chẩn đoán ung thư phổi không tế bào nhỏ di căn não có đột biến gen EGFR được điều trị thuốc ức chế tyrosine kinase kết hợp xạ phẩu dao gamma quay tại Trung tâm Y học hạt nhân và Ung bướu Bệnh viện Bạch Mai thời gian từ 01/2016 đến 12/2020. Kết quả: 50,9\% nam, tỷ lệ nam/nữ: 1,04/1, chủ yếu ở độ tuổi 50-69 (73,6\%). 43,4\% bệnh nhân hút thuốc lá, chỉ gặp ở nam giới. Triệu chứng hay gặp là triệu chứng hô hấp $54,7 \%$, tiểp đến là chứng thần kinh $39,6 \%$. Đa số bệnh nhân có chỉ số toàn trạng PS ECOG từ 0-1 $(81,1 \%)$. Giai đoan T1-2 gặp $64,2 \%$, di căn hạch $58,5 \%$, di căn não thường kết hợp di căn vị trí khác $(64,2 \%)$ trong đó hay gặp nhất là di căn xương 49,1\%, tiếp đến là di căn phổi, màng phổi $28,3 \%$, tuyến thượng thận $5,7 \%$, gan 3,7\%. Đặc diểm u di căn não: Di căn 1 ổ gặp 47\%, vị trí hay di căn là bán câu đại não $(79,2 \%)$, kích thước từ 1 $20 \mathrm{~mm}$ chiếm tỷ lệ cao nhất $(69,9 \%)$, kích thước nhỏ

${ }^{1}$ Bênh viên quân y 110

2Trung tâm Y học hạt nhân và Ung bướu, Bệnh viện Bach Mai

Chịu trách nhiệm chính: Nguyễn Văn Kiên

Email: Dr.Kien39A@gmail.com

Ngày nhận bài: 25.6.2021

Ngày phản biện khoa học: 23.8.2021

Ngày duyệt bải: 30.8 .2021

\section{Nguyễn Văn Kiên ${ }^{1}$, Phạm Cẩm Phương ${ }^{2}$}

1-10mm chiếm 20,1\%. Tỷ lệ bệnh nhân có đột biến Del19 chiếm đa số $(67,9 \%)$, Del $19 / L 858 R=2,77 / 1$. So với đột biến exon 21 , đột biến Del 19 gặp nhiều ở nhóm nữ hơn $(63,9 \%)$ sự khác biệt có ý nghĩa thống kê với $p=0,005$. Đa số bệnh nhân có nồng độ CEA, cyfra 21-1 đêu cao hơn ngưỡng bình thường (81,8\% và $70,3 \%)$. Di căn xương có mối liên hệ chặt chẽ với tình trạng tăng CEA bất thường với $\dot{p}=0,047$. Kết luân: Bênh nhân ung thư phổi di căn não có đôt biến EGFR có tỷ lệ nam/ nữ cân bằng, đột biến Del 19 chiếm đa số, găp nhiều ở nữ. CEA có đô nhay cao trong dự báo tình trạng di căn toàn thân, đặc biệt là di căn xướng.

Tư khóa: ung thư phổi di căn não, đột biến EGFR, đặc điểm bệnh nhân, CEA

\section{SUMMARY}

CHARACTERISTICS OF CLINICAL AND

PARACLINICAL OF NON-SMALL CELL LUNG CANCER PATIENTS WITH EPIDERMAL GROWTH FACTOR RECEPTOR MUTANT AND BRAIN METASTASIS TREATED AT BACH MAI HOSPITAL

Object: Characterizing of non-small cell lung cancer patients with epidermal growth factor receptor mutant and brain metastasis treated at Bach Mai Hospital. Patient and Methods: Retrospective, descriptive, cross-sectional, studying on 53 epidermal growth factor receptor, brain metastasis of mutant non-small cell lung cancer patients treated with tyrosine kinase inhibitors plus Rotating Gamma System Radiosurgery at the Nuclear Medicine and Oncology Center of Bach Mai Hospital from January 2016 to December 2020. Results: $50.9 \%$ male, male/female 
ratio: $1.04 / 1$, mainly aged $50-69$ (73.6\%). $43.4 \%$ of patients smoked, only found in men. Common symptoms were respiratory symptoms (54.7\%), followed by neurological symptoms (39.6\%). Most of the patients had a PS ECOG score from 0 to 1 $(81.1 \%)$. Stage T1-2 saw $64.2 \%$, lymph node metastasis $(58.5 \%)$, brain metastases often combined with other organs $(64.2 \%)$ of which bone metastases most commonly $(49.1 \%)$, followed by metastases in lung, pleura $(28.3 \%)$, adrenal gland $(5.7 \%)$, liver $(3.7 \%)$. Characteristics of brain metastases: Singlefocal metastasis occurred in $47 \%$, the location or metastasis was in the cerebral hemisphere (79.2\%), size from $1-20 \mathrm{~mm}$ accounted for the highest rate $(69.9 \%)$, small size $1-10 \mathrm{~mm}$ accounted for $20.1 \%$. The majority of patients with Del19 mutant (67.9\%), Del 19/L858R $=2.77 / 1$. Compared with the exon 21 mutation, the Del 19 mutation was more common in the female group $(63.9 \%)$ the difference was statistically significant with $p=0.005$. Most of the patients had abnormal CEA, cyfra 21-1 concentration (81.8\% and $70.3 \%)$. Bone metastasis was closely associated with abnormally elevated CEA with $p=0.047$. Conclusion: non-small cell lung cancer patients with epidermal growth factor receptor mutant and brain metastasis had a balanced male/female ratio, Del 19 mutations were the majority and more common in women than men. CEA has high sensitivity in predicting systemic metastases, especially bone metastases.

Keywords: brain metastasis, lung cancer, EGFR mutation, patient characteristics, CEA

\section{I. ĐẶT VẤN ĐỀ}

Theo GLOBOCAN 2020, ung thư phổi vẫn là bệnh lý ác tính hàng đầu trên thế giới về tỷ lệ mới mắc và tỷ lệ tử vong lần lượt là $11,4 \%$ và $18,0 \%$ [1]. Di căn não nguồn gốc từ ung thư phổi là bệnh cảnh hay gặp trên lâm sàng làm tiên lượng sống còn của bệnh nhân trở nên nghèo nàn. Có khoảng 10- 22\% bênh nhân ung thư phổi bị di căn não ở thời điểm chẩn đoán ban đâu và tỷ lệ di căn não sẽ tăng dần theo thời gian phát triển của bệnh [2]. Ung thư phổi di căn não không gặp đều ở các typ mô bệnh học mà có xu hướng gặp nhiều hơn ở typ ung thư biểu mô tuyến có đột biến gen EGFR. Điều trị toàn thân bằng các thuốc ức chế tyrosine kinase kết hợp điều trị tại chỗ u di căn não bằng xạ trị được xem là phác đồ điều trị chuẩn đối với nhóm bệnh nhân này. Trong đó, xạ phẫu an toàn, hiệu quả cao trong điều trị u di căn não số lượng hạn chế, được chỉ định cho bệnh nhân di căn não từ 1-3 u, kích thước u não $<5 \mathrm{~cm}$. Di căn não đa ổ thì xa trị toàn não lại được chỉ định nhờ khả năng kiểm soát u di căn nã̃o tốt hơn, tuy vậy bệnh nhân phải chịu di chứng suy giảm nhận thức ảnh hưởng nhiêuu đến chất lượng cuộc sống [3]. Vì vậy, lý tưởng nhất là bệnh nhân được phát hiện di căn não sớm, số lượng u di căn não hạn chế, điều trị bằng phác đồ kết hợp thuốc thuốc ức chế tyrosine kinase và xạ phâu u di căn não. Phác đồ đã được áp dụng trong điều trị nhóm bệnh nhân này ở nhiêu trung tâm ung bướu lớn trên thế giới. Tuy nhiên, đặc điểm khác biệt của nhóm bệnh nhân so với bệnh cảnh ung thư phổi không tế bào nhỏ giai đoạn lan tràn nói chung, hiệu quả và các yếu tố ảnh hưởng đến kết quả của sự kết hợp giữa thuốc thuốc ức chế tyrosine kinase và xạ phẩu điều trị nhóm bệnh nhân này còn nhiều vấn đề chưa rõ ràng, kết quả của một số nghiên cứu còn có nhiều khác biệt. Ở Việt Nam, phác đồ thuoốc thuốc ức chể tyrosine kinase kết hợp xạ phẫu được áp dụng tại một số Bệnh viện điêu trị nhóm bệnh nhân này. Tuy nhiên chưa có nghiên cứu nào mô tả đặc điểm của nhóm bệnh nhân này và khả năng vận dụng vào chẩn đoán và điều trị. Vì vây, chúng tôi thức hiện đề tài này nhẳm mục tiêu: Mô tả đăc điểm nhóm bệnh nhân ung thư phổi không tế bào nhỏ di căn não có đột biến EGFR điều trị tại Bệnh viện Bạch Mai.

\section{II. ĐỐI TƯợNG VÀ PHƯƠNG PHÁP NGHIÊN CỨU}

- Đối tượng nghiên cứu: 53 bênh nhân được chẩn đoán ung thư phổi không tể bào nhỏ có đột biến gen EGFR, được điều trị bằng thuốc ức chế tyrosine kinase kết hợp xạ phẩu dao gamma quay tại Trung tâm $Y$ học hạt nhân và Ung bướu Bệnh viện Bạch Mai thời gian từ 01/2016 đến 12/2020.

- Tiêu chuẩn lựa chọn là bệnh nhân có chẩn đoán mô bệnh học là ung thư biểu mô tuyến, có đột biến EGFR nhạy thuốc thuốc ức chế tyrosine kinase thế hệ 1,2. U di căn não số lượng từ 1-3 u, kích thước u $<5 \mathrm{~cm}$. Không có tiền sử điều trị trước đó ung thư phổi bằng hóa chất, phẫu thuật, xạ trị, không mắc các bênh lý thần kinh như rối loạn tâm thần, thiểu năng trí tuệ, động kinh.

- Thiết kế nghiên cứu: Hồi cứu, mô tả, cắt ngang

- Phương pháp thu thập số liệu: Thu thập thông tin từ hồ sơ bệnh án, kết hợp phỏng vấn bệnh nhân, người nhà. Xử lý và phẩn tích số liệu bẳng phần mềm SPSS 20.0.

- Đạo đức nghiên cứu: Thông tin của đối tượng nghiên cứu được đảm bảo giữ bí mật và chỉ dùng cho mục đích nghiên cứu.

- Quy trình điêu trị: Bệnh nhân thỏa mãn tiêu chuẩn lựa chọn được chỉ định điều trị toàn thân bằng thuốc thuốc ức chế tyrosine kinase, hội chẩn xác định kế hoạch xạ phẫu. Sau xạ phẫu điều trị chống phù não, duy trì tiếp thuốc thuốc ức chế tyrosine kinase, định kỳ sau mỗi 3 tháng theo dõi đáp ứng điêu trị và tình trạng tiến 
triển. Các thông tin thời điểm bắt đầu điều trị được ghi nhận qua hồ sơ bệnh án và phỏng vấn bệnh nhân, người nhà.

\section{KẾT QUẢ NGHIÊN CỨU}

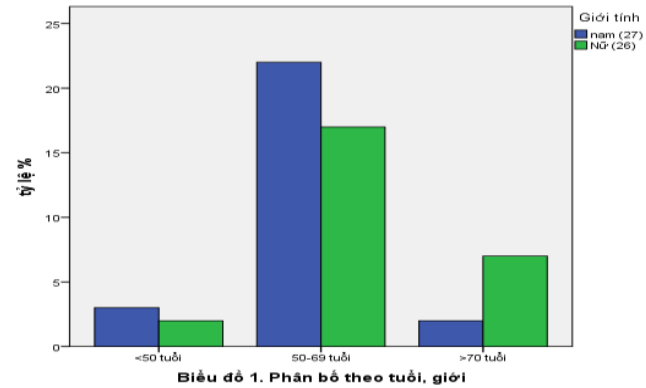

Nhận xét: Tuổi trung bình là $61 \pm 9,0$ tuổi, bệnh nhân trẻ nhất là 38 tuổi, bệnh nhân lớn nhất là 84 tuổi. Nhóm tuổi từ 50-69 chiếm tỷ lê nhiều nhất $(73,6 \%)$. Nam gặp 50,9\%, tỷ lẹ̉ nam/nữ ngang nhau $(1,04 / 1)$.

Bảng 1. Triệu chứng lâm sàng chính

\begin{tabular}{|c|c|c|c|}
\hline \multicolumn{2}{|c|}{ Triệu chứng } & $\mathbf{n}$ & Tỷ lệ $\%$ \\
\hline \multirow{2}{*}{$\begin{array}{c}\text { Thần kinh } \\
(n=21)\end{array}$} & Đau đâu & $\mathbf{1 5}$ & $\mathbf{2 8 , 3}$ \\
\cline { 2 - 4 } & Yếu liệt & 8 & 15,1 \\
\cline { 2 - 4 } & Co giật động kinh & 1 & 1,9 \\
\hline
\end{tabular}

\begin{tabular}{|c|c|c|c|}
\hline & Rối loạn ngôn ngữ & 1 & 1,9 \\
\hline \multirow{3}{*}{$\begin{array}{c}\text { Hô hấp } \\
(n=29)\end{array}$} & Ho kéo dài & $\mathbf{2 0}$ & $\mathbf{3 7 , 7}$ \\
\cline { 2 - 4 } & Ho máu & 3 & 5,7 \\
\cline { 2 - 4 } & Đau ngực & $\mathbf{1 4}$ & $\mathbf{2 6 , 4}$ \\
\cline { 2 - 4 } & Khó thớ & 3 & 5,7 \\
\hline \multirow{2}{*}{$\begin{array}{c}\text { Chèn ép } \\
\text { (n=12) }\end{array}$} & Đau xương & $\mathbf{1 1}$ & $\mathbf{2 0 , 8}$ \\
\hline \multirow{2}{*}{ Khác } & Phù chân & 1 & 1,9 \\
\cline { 2 - 4 } & Khám định kỳ & 1 & 1,9 \\
\cline { 2 - 4 } & Bệnh khác & 2 & 3,7 \\
\hline
\end{tabular}

Nhân xét: Triêu chứng hay gặp nhất là triệu chứng hô hấp $(54,9 \%)$, tiếp theo là triệu chứng thần kinh (39,6\%).

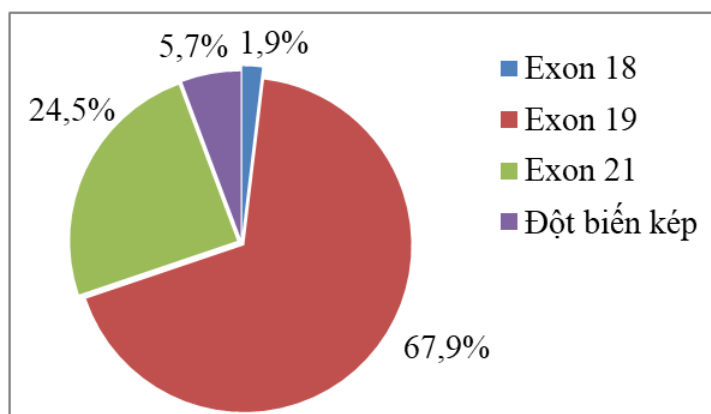

Biểu đồ 2. Phân bố đột biến gen EGFR

Bảng 2. Tình trạng đột biến theo một số yêu tố

\begin{tabular}{|c|c|c|c|c|c|c|c|}
\hline \multicolumn{2}{|c|}{ Yếu tố } & $\begin{array}{c}\text { Exon } \\
19(36)\end{array}$ & $\begin{array}{l}\text { Exon } 21 \\
\text { (13) }\end{array}$ & $\begin{array}{l}\text { Đột biến } \\
\text { khác (4) }\end{array}$ & Tổng & Tỉ lệ \% & $\mathbf{p}$ \\
\hline \multirow{2}{*}{ Giới } & Nũ̃ & 23 & 2 & 1 & 26 & 49,1 & \multirow{2}{*}{0,005} \\
\hline & Nam & 13 & 11 & 3 & 27 & 50,9 & \\
\hline \multirow{3}{*}{ Nhóm tuổi } & $<50$ & 3 & 1 & 1 & 5 & 9,4 & \multirow{3}{*}{0,96} \\
\hline & $50-69$ & 26 & 10 & 2 & 38 & 71,7 & \\
\hline & $\geq 70$ & 7 & 2 & 1 & 10 & 18,9 & \\
\hline \multirow{2}{*}{ Tiền sử hút thuốc } & Không & 23 & 5 & 1 & 29 & 54,7 & \multirow{2}{*}{0,19} \\
\hline & Có & 13 & 8 & 3 & 24 & 45,3 & \\
\hline \multirow{2}{*}{ Giai đoạn T } & T1-2 & 23 & 9 & 2 & 34 & 64,2 & \multirow{2}{*}{0,80} \\
\hline & T3-4 & 13 & 4 & 2 & 19 & 35,8 & \\
\hline \multirow{2}{*}{ Giai đoạn N } & N0 & 18 & 3 & 1 & 22 & 41,5 & \multirow{2}{*}{0,29} \\
\hline & N1-3 & 18 & 10 & 3 & 31 & 58,5 & \\
\hline \multirow{2}{*}{ Số u di căn não } & 1 & 18 & 8 & 1 & 27 & 50,9 & \multirow{2}{*}{0,75} \\
\hline & $2-3$ & 18 & 5 & 3 & 26 & 49,1 & \\
\hline \multirow{3}{*}{$\begin{array}{l}\text { Kích thước u di } \\
\text { căn não (mm) }\end{array}$} & $1-10$ & 7 & 4 & 0 & 11 & 20,7 & \multirow{3}{*}{0,16} \\
\hline & $11-30$ & 28 & 8 & 3 & 39 & 73,6 & \\
\hline & $31-40$ & 2 & 0 & 1 & 3 & 5,7 & \\
\hline \multirow{2}{*}{ Di căn cơ quan } & 1 & 10 & 5 & 2 & 17 & 32,1 & \multirow{2}{*}{0,5} \\
\hline & $2-4$ & 26 & 8 & 2 & 36 & 67,9 & \\
\hline \multirow{2}{*}{$\begin{array}{c}\text { CEA trước điều trị } \\
(n=44)\end{array}$} & $\leq 5,0$ & 5 & 3 & 0 & 8 & 18,2 & \multirow{2}{*}{0,86} \\
\hline & $>5,0$ & 23 & 9 & 4 & 36 & 81,8 & \\
\hline \multirow{2}{*}{$\begin{array}{l}\text { Cyfra 21-1 trước } \\
\text { điều trị }(n=37)\end{array}$} & $<3,3$ & 7 & 3 & 1 & 11 & 29,7 & \multirow{2}{*}{1,00} \\
\hline & $\geq 3,3$ & 17 & 6 & 3 & 26 & 70,3 & \\
\hline
\end{tabular}

Nhận xét: So với đột biến exon 21, đột biến exon 19 gặp nhiều ở nhóm nữ hơn (63,9\%), sự khác biệt có ý nghĩa thống kê với $p=0,005$. Đa số bênh nhân ở giai đoạn T1-T2 (64,2\%), và đã di căn hạch (58,5\%). Tỷ lệ bệnh nhân di căn cơ quan khác đồng thời với di căn não cao $(67,9 \%)$, kích thước u não từ 11-30mm nhiều nhất (73,6\%). 
VIETNAM MEDICAL JOURNAL N02 - SEPTEMBER - 2021

\begin{tabular}{|c|c|c|c|c|c|c|}
\hline \multicolumn{2}{|c|}{ Yếu tố } & CEA $\leq 5,0$ & CEA $>5,0$ & Tống & Tỉ lệ \% & \multirow{3}{*}{$\frac{\mathbf{p}}{0,70}$} \\
\hline \multirow{2}{*}{ Giới } & Nũ̃ & 3 & 19 & 22 & 50,0 & \\
\hline & Nam & 5 & 17 & 22 & 50,0 & \\
\hline \multirow{3}{*}{ Nhóm tuổi } & $<50$ & 1 & 3 & 4 & 9,1 & \multirow{3}{*}{0,54} \\
\hline & $50-69$ & 5 & 27 & 29 & 72,7 & \\
\hline & $\geq 70$ & 2 & 6 & 8 & 18,2 & \\
\hline \multirow{2}{*}{$\begin{array}{l}\text { Tiền sử hút } \\
\text { thuốc }\end{array}$} & Không & 4 & 21 & 25 & 56,8 & \multirow{2}{*}{0,71} \\
\hline & Có & 4 & 15 & 19 & 43,2 & \\
\hline \multirow{2}{*}{$\begin{array}{c}\text { Giai đoan u } \\
\text { phôi }\end{array}$} & T1-2 & 5 & 23 & 34 & 63,6 & \multirow{2}{*}{1,00} \\
\hline & T3-4 & 3 & 13 & 19 & 36,4 & \\
\hline \multirow{2}{*}{$\begin{array}{l}\text { Di căn hạch } \\
\text { vùng }\end{array}$} & N0 & 2 & 16 & 18 & 40,9 & \multirow{2}{*}{0,44} \\
\hline & N1-3 & 6 & 20 & 26 & 59,1 & \\
\hline \multirow{2}{*}{ Di căn xương } & Không & 7 & 15 & 22 & 50,0 & \multirow{2}{*}{0,047} \\
\hline & Có & 1 & 21 & 22 & 50,0 & \\
\hline \multirow{2}{*}{$\begin{array}{l}\text { Di căn phốí/ } \\
\text { màng phổi }\end{array}$} & Không & 3 & 27 & 30 & 68,2 & \multirow{2}{*}{0,09} \\
\hline & Có & 5 & 9 & 14 & 31,8 & \\
\hline
\end{tabular}

Nhận xét: Di căn xương có tỷ lệ tăng CEA cao hơn nhóm không di căn xương, sự khác biệt có ý nghĩa thống kê với $p<0,05$. Không có sự khác biệt về nồng độ CEA ở giai đoạn u, hạch vùng, di căn phổi, màng phổi, tuổi, giới, tiền sử hút thuốc, với p> 0,05.

\section{BÀN LUẬN}

Tỷ lệ nam giới là $50,9 \%$ xấp xỉ bằng tỷ lệ nữ giới, nam/nữ =1,04/1. Đa số bệnh nhân độ tuổi từ 50 - 69 tuối $(73,6 \%)$ (Biểu đồ 1). Ung thư phổi nói chung gặp ở nam nhiều hơn, nghiên cứu của Reza Pakzad và cs trên người Châu Á ( $\mathrm{n}=$ $1,033,881$ ca mới mắc) tỷ lệ nam/nữ= 2,46 [4]. Lý giải điều này, nhóm bệnh nhân chúng tôi lựa chọn là nhóm ung thư biểu mô tuyến, có đột biển gen EGFR, nhóm bệnh nhân này thường gặp nhiều hơn ở phụ nữ, người không hút thuốc. Trên nhóm bênh nhân tương đồng, nghiên cứu của Magnuson và cộng sự $(n=351)$, xu hướng gặp nhiêu ở nữ thể hiện rõ rệt hơn với tỷ lệ nam/nữ $=0,48$ [5]. Triệu chứng lâm sàng chính là hô hấp $(54,7 \%)$ và thần kinh $(39,6 \%)$, tỷ lệ này thấp hơn trong nghiên cứu của Phạm Văn Thái, triệu chứng hô hấp gặp $90,1 \%$ và thần kinh gặp 85,2\% [6] (Bảng 1). Lý giải điều này, nghiên cứu của chúng tôi có tỳ lệ u phổi giai đoạn sớm T1-2 nhiêu hơn $(64,2 \%$ so với $43,2 \%)$, có tỷ lệ u di căn não kích thước $<10 \mathrm{~mm}$ nhiều hơn (20,8\% so với 3,7\%). Kích thước u < $15 \mathrm{~mm}$ thường khó phát hiện hơn trên chụp cắt lớp vi tính so não, các bênh nhân di căn não kích thước nhỏ thường không có triệu chứng và đều được phát hiện nhờ tầm soát bằng chup cộng hưởng từ sọ não. Tương tự với triệu chứng đau xương, tỷ lệ bệnh nhân có triệu chứng thấp hơn nhiều so với tỷ lệ phát hiện $(20,6 \%$ so với $49,1 \%$ ) nhờ tầm soát bằng xạ hình xương. Phát hiện sớm khi kích thước tổn thương còn nhỏ, chưa có triệu chứng tại chố và thể trạng bệnh nhân còn tốt là yếu tố thuận lợi cho tuân thủ phác đồ và hiệu quả điều tri. Trong nghiên cứu của chúng tôi, tỷ lệ bệnh nhân có đột biến exon 19 chiếm đa số $(67,9 \%)$, tỷ lệ exon 19/exon 21 $=2,77 / 1$. Tỷ lệ đột biến gen cũng khác nhau tùy từng vùng, chủng tộc, với người châu Âu đột biến gen Del 19 gặp nhiều hơn L858R trên exon 21, trong khi đó ở người châu Á, 2 đột biến có xu hướng chia sẻ tỷ lệ tương đương nhau. Tỷ lệ phân bố đột biến gen ở nhóm bệnh nhân ung thư phổi không tế bào nhỏ di căn não trong nghiên cứu của chúng tôi cũng tương tự kết quả của Magnuson $(n=100)$, tỷ lê Del19/L858R $=1,74$ [5]. So với các đột biến khác, bênh nhân có đột biến exon 19 đa số gă̆p ở nữ giới $(63,9 \%)$, tỷ lêe nữ/nam=1,76/1, sự khác biệt có ý nghĩa thống kê với $\mathrm{p}<0,01$. Kết quả nghiên cứu của chúng tôi phù hợp với các nghiên cứu thế giới, tỷ lệ đột biến gen del 19 gặp nhiều hơn ở nữ giới[7]. Đột biến del 19 cho tiên lượng đáp ứng và duy trì đáp ứng tốt hơn khi điều trị bằng erlotinib. Tỷ lệ bệnh nhân có nồng độ CEA, cyfra 21-1 vượt ngưỡng đều cao hơn $>70 \%$, đặc biệt là nồng độ CEA $(81,8 \%)$. Tỷ lệ này cao hớn nghiên cứu của Pham Văn Thái, ĊEA vượt ngưỡng chỉ chiếm $69,1 \%$, Cyfra $21-1$ là $50,6 \%$. Điêu này được giải thích là nhóm bệnh nhân nghiên cứu đều là ung thư biểu mô tuyến, tỷ lệ di căn xương cao $(49,1 \%)$, trong khi nghiên cứu của Phạm Văn Thái có cả các bệnh nhân ung thư biểu mô vảy và đã chủ động loại trừ các bệnh nhân di căn xương. Nghiên cứu của Dong Soo Lee và cs chì ra CEA tăng cao liên quan chặt chẽ đến một số yếu tố: typ mô học ung thư biểu mô không vảy $(p=0,002)$, tình trạng di căn não $(p=0,005)$, di 
căn xương $(p=0,001)$, trong khi đó là các yếu tố tiến triển u phổi, hạch vùng, di căn phổi, màng phổi mối liên quan chưa có ý nghĩa thống kê với $p>0,05[8]$. Nghiên cứu của chúng tôi, nhóm bệnh nhân đã là tuýp UTBM tuyến, di căn não, nển chúng tôi chỉ phát hiện di căn xương có mối liên hệ chă̆t chẽ đến tình trạng tăng CEA vượt ngưỡng với $p<0,05$. CEA tăng cao là yếu tố tiền lượng tình trạng di căn toàn thân kết hợp, vì vậy trền lâm sàng cần khám xét đánh giá tỳ mỉ phát hiện các tổn thương di căn khác.

\section{KẾT LUẦN}

- Nam gặp 50,9\%, tỷ lệ nam/nữ ngang nhau $(1,04 / 1)$, nhóm tuổi 50-69 gặp nhiều nhất $(73,6 \%)$. Hút thuốc lá chỉ gặp ở nam, tỷ lệ hút thuốc chung (45,3\%).

- Triệu chứng lâm sàng thường gặp: hô hấp $(54,7 \%)$, triệu chứng thần kinh $(39,6 \%)$

- Giai đoạn T1-2 chiếm đa số $64,2 \%$, di căn hạch chiếm $58,5 \%$, di căn não kết hợp di căn cơ quan khác chiếm $67,9 \%$, hay gặp nhất là di căn xương $(49,1 \%)$ và di căn phổi màng phổi $(28,3 \%)$.

- Đột biến Del19 chiếm đa số $(67,9 \%)$. Đột biến del 19 gặp nhiều ở nữ hơn, $p<0,01$.

- CEA tăng cao là yếu tố tiên lượng tình trạng di căn toàn thân, đặc biệt tình trạng di căn xương.
1. Sung H, Ferlay J, Siegel R L (2021). "Global Cancer Statistics 2020: GLOBOCAN Estimates of Incidence and Mortality Worldwide for 36 Cancers in 185 Countries". 71 (3), 209-249.

2. Davis F G, Dolecek T A, McCarthy B J, et al (2012). "Toward determining the lifetime occurrence of metastatic brain tumors estimated from 2007 United States cancer incidence data". Neuro Oncol, 14 (9), 1171-1177.

3. Mai Trong Khoa (2020). Hướng dẫn chẩn đoán và điều trị một số bệnh lý ung bướu, Nhà xuất bản Y học,

4. Pakzad $\mathbf{R}$, Mohammadian-Hafshejani $\mathbf{A}$ Ghoncheh $M$, et al (2015). "The incidence and mortality of lung cancer and their relationship to development in Asia". Transl Lung Cancer Res, 4 (6), 763-774.

5. Magnuson $\mathbf{W} \mathbf{J}$, Lester-Coll $\mathbf{N ~ H , ~ W u ~ A ~ J , ~ e t ~ a l ~}$ (2017). "Management of Brain Metastases in Tyrosine Kinase Inhibitor-Naïve Epidermal Growth Factor Receptor-Mutant Non-Small-Cell Lung Cancer: A Retrospective Multi-Institutional Analysis". J Clin Oncol, 35 (10), 1070-1077.

6. Phạm Văn Thái (2014). Nghiên cứu điều trị ung thư phổi không tế bào nhỏ di căn não bằng hoá xạ tri, Luân án Tiên sỹ y học, Trường Đai học y Hà Nôi.

7. Kelly W J, Shah i J, Subramaniam D S (2018). "Management of Brain Metastases in Epidermal Growth Factor Receptor Mutant NonSmall-Cell Lung Cancer". Front Oncol, 8208.

8. Lee D S, Kim S J, Kang J H, et al (2014). "Serum Carcinoembryonic Antigen Levels and the Risk of Whole-body Metastatic Potential in Advanced Nonsmall Cell Lung Cancer". J Cancer, 5 (8), 663-669.

\section{TÀI LIÊU THAM KHẢO}

\section{ĐÁNH GIÁ HIẾU QUẢ ĐIỀU TRI ĐAU Ở GIAI ĐOẠN TRÂMM CẢM NGƯ ỜI GIÀ}

\section{TÓM TẮT.}

Mục tiêu: Đánh giá hiệu quả điều trị đau ở giai đoạn trầm cảm ngưới già. Đối tượng và phương pháp: Sử dụng phương pháp mô tả cắt ngang, phân tích hiệu quả điều trị đau bằng phỏng vấn trực tiếp kết hợp đánh giá mức độ đau trên thang VAS, mức độ trầm cảm trên thang GDS, tham kháo hồ sơ bệnh án của 50 bệnh nhân người già ở giai đoạn trầm cảm có đau điều trị nội trú tại Viện Sức khỏe Tâm thần,- Bệnh viện Bạch Mai. Kết quả: $84,0 \%$ bệnh nhân sử dụng phối hợp thuốc chống trầm cảm, an thần kinh và bình thần, số lượng vị trí đau thuyên giảm $2,26 \pm 1,45$, mức độ đau VAS giảm 3,2 \pm 0,99 điểm, mức độ trầm

\footnotetext{
${ }^{1}$ Trường Đại học Y Hà Nọi

${ }^{2}$ Viện Sức khoé Tâm thằn - Bệnh viện Bạch Mai

Chịu trách nhiệm chính: Vũ Thị Lan

Email: lanthudrnd1988@gmail.com

Ngày nhận bài: 24.6.2021

Ngày phản biên khoa hoc: 20.8.2021

Ngày duyệt bài: 27.8.2021
}

Vũ Thị Lan ${ }^{1,2}$, Nguyễn Văn Tuấn ${ }^{1,2}$ cảm trên thang GDS thuyên giảm 7,3 $\pm 7,21$ điểm có sự khác biệt có ý nghĩa thống kê, không có sự khác biệt thuyên giảm đau ở các mức độ trầm cảm, kháng cholinergic là tác dụng không mong muốn hay gặp nhất 52,0\%. Kết luận: phần lớn bệnh nhân dùng phối hợp thuốc, triệu chứng đau cải thiện đáng kể cùng thuyên giảm trầm cảm. Tuy nhiên không có sự khác biệt thuyên giảm đau ở các mức độ trầm cảm. Tác dụng không mong muốn của thuốc hay gặp ở trầm cảm người già là kháng cholinergic.

Từ khóa: người già, trầm cảm, đau, thuyên giảm.

\section{SUMMARY}

\section{EFFICACY OF TREATMENT FOR PAINFUL SYMPTOMS AMONG HOSPITALIZED ELDERLY DEPRESSION}

Objective: To evaluate the effectiveness of treatment for elderly depression with pain. Subjects and methods: Using a cross-sectional descriptive method, analyzing the effectiveness of treatment for pain by directly interviewing and testing VAS, GDS on 50 the elderly in-patients diagnosed major depressive 